\title{
Observationally-constrained estimates of global fine-mode AOD
}

\author{
K. Lee and C. E. Chung \\ Dept. Environmental Science \& Engineering, Gwangju Institute of Science and Technology, Gwangju, Korea \\ Correspondence to: C. E. Chung (eddy@gist.ac.kr)
}

Received: 30 November 2012 - Published in Atmos. Chem. Phys. Discuss.: 10 December 2012

Revised: 28 February 2013 - Accepted: 1 March 2013 - Published: 13 March 2013

\begin{abstract}
Small aerosols are mostly anthropogenic, and the fine-mode aerosol optical depth (fAOD) can be used to infer anthropogenic aerosol amounts. We estimate AOD and fAOD globally on a monthly time scale from 2001 to 2010 by integrating monthly satellite-based (MODIS and MISR) and ground-based (AERONET) observations. For fAOD, three integration methods are developed to utilize global coverage by satellite data and maximize the influence of AERONET data. We evaluate each method by applying the method without a few randomly-chosen AERONET data and comparing its output with the few AERONET data. The best method of the three is based on integrating the Ångström exponent (AE) data from MODIS, MISR and AERONET, and its output is closer to AERONET fAOD accuracy than MODIS or MISR fAOD over both ocean and land.

Using our integrated data, we find that the global 20012010 average of $500 \mathrm{~nm}$ AOD and fAOD is 0.17 and 0.089 , respectively. Eastern China as a region shows the largest decadal-mean fAOD. The linear trend of global AOD or global fAOD from 2001 to 2010 is found to be slightly negative. This decreasing trend is particularly pronounced over the West (Western Europe and US/Canada combined) where AOD and fAOD reductions are about $-20 \%$. By contrast, fAOD in India and eastern China combined increased slightly. These results reflect the overall anthropogenic aerosol emission reduction in the West, and stagnating conditions in Asia. Moreover, our results in the West are consistent with the so-called surface brightening phenomenon in the recent decades.
\end{abstract}

\section{Introduction}

Solar radiation reaching the Earth's surface decreased in many regions of the world from the 1950's to the 1980's (e.g. Stanhill and Moreshet, 1992; Gilgen et al., 1998; Stan- hill and Cohen, 2001; Liepert, 2002), a phenomenon called "global dimming". Since then, an increase in surface solar radiation has been observed in some regions, and this has been referred to as "global brightening" (Wild et al., 2005). One of the main causes of the global dimming and brightening is widely believed to be the change in the amount of atmospheric aerosols (Streets et al., 2009; Norris and Wild, 2009; Riihimaki et al., 2009).

Aerosols vary in time and space, and increasing aerosol amounts generally lower the downward surface solar radiation. Aerosols are emitted by anthropogenic sources as well as natural sources. Natural aerosols consist primarily of dust and sea salt particles, and these aerosols are mostly coarse (super-micron diameter) in size. On the other hand, small aerosols in the submicron sizes are usually associated with black carbon, organic aerosol, sulfate, nitrate, etc., and these small particles are mostly anthropogenic. Some dust particles are in the submicron sizes and some of carbonaceous aerosols and sulfate are of natural origins such as wildfire, but generally small (or large) particles are understood as anthropogenic (or natural) particles. These two size groups usually co-exist in the form of fine and coarse modes in the ambient atmosphere. Carbon rich anthropogenic aerosols in Asia tend to have lower single scattering albedo (SSA) values in the visible and near infrared than natural aerosols (Chung et al., 2005), and lower SSAs have a higher efficiency in reducing the surface solar radiation (Chung, 2012). Therefore, if aerosol amount changes over time, it would be very important to partition the change between anthropogenic and natural ones, especially in Asia, given the linkage to dimming and brightening phenomena.

The importance of small particles is amplified, when human health is an issue. Dockery et al. (1993) showed a strong relationship between mortality and air pollution with fine particulates, and Schwartz and Neas (2000) reported that 
Table 1. Summary of the acronyms.

\begin{tabular}{ll}
\hline AOD & Aerosol optical depth (for all particles) \\
fAOD & Fine-mode aerosol optical depth \\
mAOD & Aerosol optical depth for medium-size particles \\
cAOD & Coarse-mode aerosol optical depth \\
AAOD & $\begin{array}{l}\text { Absorption aerosol optical depth; } \\
=(1-\text { SSA }) \times \text { AOD }\end{array}$ \\
SSA & Single scattering albedo \\
AE & Ångström exponent for AOD \\
FMF & Fine mode fraction; = fAOD/AOD \\
\hline
\end{tabular}

small particles are more harmful for human respiratory health than coarse-sized particles.

This study is aimed at providing global and regional estimates of small-sized aerosol amounts. Such global estimates are already available in the form of the aerosol optical depth (AOD; see Table 1 for the acronyms) and fine-mode AOD (fAOD) derived from satellite measurements. Reliable global AOD can be obtained from MODIS (Moderate Resolution Imaging Spectroradiometer) and MISR (Multi-angle Imaging Spectroradiometer) satellite sensors. The fine-mode fraction (FMF) of total AOD is also retrieved and its retrieval algorithm depends heavily on the spectral variation of AOD (e.g. Remer et al., 2005). Due to the uncertainties in the spectral variation of land surface albedo, satellite-derived FMF is not reliable over land yet (see Sect. 2.3 for details). The lack of reliable global FMF hinders accurate observational estimates of global aerosol radiative forcing. All the published observational estimates of global aerosol radiative forcing use aerosol simulation models to distinguish natural aerosols from anthropogenic ones over the globe or at least over the land (Chung et al., 2005; Bellouin et al., 2005).

Alternative estimates of AOD and FMF than those from satellite observations are offered by ground-based aerosol networks such as the AErosol RObotic NETwork (AERONET; Holben et al., 1998). AERONET data have been widely used to validate satellite-derived data (Liu et al., 2004; Christopher and Wang, 2004; Martonchik et al., 2004; Kahn et al., 2005, 2010; Chu et al., 2002; Remer et al., 2002, 2005). In addition, AERONET FMF is reliable over both land and ocean (again see Sect. 2.3 for details). Unfortunately, because AERONET stations are sparsely distributed, AERONET data alone are inadequate for global or regional mean estimates. The goal of the present study is to combine AERONET, MODIS and MISR data to give optimal fAOD and AOD estimates over the entire globe. Our data integration strategy is to optimally combine the three datasets so that regional and monthly (and annual) averages would be accurate. In comparison, Zhang and Reid (2006), for instance, refined MODIS AOD by use of AERONET data for use in real-time aerosol data assimilation, rather than combining the two data sets.
Chung et al. (2005) also combined MODIS AOD and AERONET AOD. The present study is a significant expansion of Chung et al. (2005), in that (a) we bring in MISR data as well, (b) more importantly we address fAOD as well as AOD, and (c) we look at the trend of global and region mean AOD and fAOD as well as the climatology. Not only would the AOD and fAOD trend be useful for global dimming studies, but the trend in global and regional mean fAOD would also serve as an independent and powerful measure of changes in global and regional anthropogenic aerosol emissions. Available near-ground measurements of aerosol concentration are not adequate for global or regional averages, as the monitoring sites are unevenly distributed. Secondly, AOD (or fAOD) is only a good indicator of near-ground aerosol concentration if the aerosol vertical profile is known, as corroborated by van Donkelaar et al. (2010). Nevertheless, as far as long-term trends are concerned, a decadal fAOD (or AOD) trend is likely a good indicator of the decadal change in near-ground aerosol concentration because areaaveraged aerosol vertical structure is unlikely to have significant decadal changes.

Aerosol data used in this study are described in Sect. 2. The techniques to integrate satellite and ground-based data are discussed in Sect. 3 (for AOD) and Sect. 4 (for fAOD). We discuss the trends of global and regional averages of AOD and fAOD in Sect. 5. Conclusion follows in Sect. 6.

\section{Data}

Table 2 summarizes the datasets used here. Below, we discuss the datasets in detail.

\subsection{MODIS}

The Moderate Resolution Imaging Spectroradiometer (MODIS) sensors onboard the Terra (launched in December 1999) and Aqua (launched in May 2002) satellites scan the atmosphere and the ocean surface in an unprecedented manner. The MODIS aerosol algorithm derives the ambient AOD over the oceans (Tanré et al., 2001) and over dark land surfaces (Kaufman et al., 1997; Levy et al., 2010). On the other hand, the MODIS observations and algorithms are not adequate to retrieve AODs over bright surfaces such as deserts and snow surfaces (Kaufman et al., 1997). The MODIS algorithm not only offers the retrieved data but also gives the Quality Assurance Confidence (QAC) flag for the data (Levy et al., 2010). QAC varies from 0 (i.e. lowest quality) to 3 (highest quality). Levy et al. (2010) found that MODIS data agree with AERONET data better when only $\mathrm{QAC}=3$ data are utilized. We downloaded the M3 product of Collection 5.1 data file, which is the level 3.0 and latest monthly mean product. In this product, we use the $550 \mathrm{~nm}$ AOD that was generated only with QAC $=3$ data in computing $1^{\circ} \times 1^{\circ}$ monthly means. For FMF as 
Table 2. Datasets used in this study.

\begin{tabular}{lllll}
\hline Measurement & Time period & Data version & Spatial resolution & Wavelength (in nm) \\
\hline AERONET & Jan 2001-Dec 2010 & Monthly level-2 & & $440,675,870,500$ \\
& & & & (AOD and fine-mode fraction) \\
MODIS/Terra & Jan 2001-Dec 2010 & Monthly level-3 & $1^{\circ} \times 1^{\circ}$ & $470,550,660,870$ \\
MODIS/Aqua & Jul 2002-Dec 2010 & Monthly level-3 & $1^{\circ} \times 1^{\circ}$ & $470,550,660,870$ \\
MISR/Terra & Jan 2001-Dec 2010 & Monthly level-3 & $0.5^{\circ} \times 0.5^{\circ}$ & $443,555,670,865$ \\
\hline
\end{tabular}

well as multi-wavelength AOD for computing AE, we use the QA-mean data due to the data availability. The QA mean is a monthly mean method whereby higher QA data receive higher weighting. Thus, there is slight inconsistency between the $550 \mathrm{~nm}$ AOD and FMF/AE we use here, but as will be shown later this inconsistency is not an issue.

$550 \mathrm{~nm}$ AOD, FMF and multi-wavelength AOD data originally on the $1^{\circ}$ by $1^{\circ}$ spatial resolution are converted into the T42 resolution (approximately $2.8^{\circ}$ by $2.8^{\circ}$ grid) from 2001 to 2010, as follows. Over each T42 gridbox in each month, there are typically many values from the $1^{\circ} \times 1^{\circ}$ Terra and Aqua data combined. If there are at least five values in a $\mathrm{T} 42$ gridbox, we use the median to represent that $\mathrm{T} 42$ grid. Median, instead of arithmetic averaging, is a tool we choose in reducing cloud contamination further. In a sensitivity test, we replace these median values by arithmetic average values. We find that the global and decadal (2001-2010) mean AOD differs insignificantly between the two averaging methods. However, the 98th percentile AOD at $550 \mathrm{~nm}$ is about $50 \%$ lower in the median method than in the average method. This reduction is due mainly to removing many of extremely-large values in excess of 1.0. Monthly $550 \mathrm{~nm}$ AOD exceeding 1.0 appears quite unrealistic in many cases and probably pertinent largely to cloud contamination, and thus eliminating many of these extreme values should be viewed as improving the quality of AOD.

The AE over the ocean is obtained using the T42resolution AODs at 470,550, 660 and $870 \mathrm{~nm}$, by linear regression in logarithmic coordinates. The $550 \mathrm{~nm}$ AOD in this case is from the QA mean for consistency. fAOD at multiple wavelengths is obtained using multi-wavelength FMF and AOD data.

\subsection{MISR}

The Multi-angle Imaging Spectroradiometer (MISR) instrument aboard the Terra satellite (again, launched in December 1999) retrieves key aerosol optical properties, such as AOD, over the oceans and the continents including highly reflective surfaces like deserts. We downloaded the CGAS MIL3MAE.004 product for the study. This is the level 3.0 data that have been validated at Stage 3 (for AOD) and at Stage 2 (for fine and medium mode fractions). Out of this monthly product, we extracted AOD, fAOD, mAOD, and cAOD (see Table 1 for the acronyms). These parameters orig- inally available on the $0.5^{\circ}$ by $0.5^{\circ}$ spatial resolution are converted into the T42 resolution using the median method that we adopted for the MODIS data processing in Sect. 2.1. The effect of using the median method over the arithmetic averaging is assessed again, yielding similar results to that for MODIS AOD. The global and decadal (2001-2010) mean MISR AOD at $550 \mathrm{~nm}$ shows a tiny difference (about 0.01 ) between the median and arithmetic average methods. In case of the 98th percentile value, AOD is about $40 \%$ lower in the median method than in the average method.

MISR AE is computed using the T42-resolution AOD values at $443,555,670$ and $865 \mathrm{~nm}$. Where necessary, we logarithmically interpolate AOD (or fAOD) to the desired wavelength.

\subsection{AERONET}

The AErosol RObotic NETwork (AERONET) is a groundbased aerosol network consisting of worldwide automatic sun- and sky-scanning spectral radiometers (Holben et al., 1998). AERONET derives AOD from direct solar radiation measurements and the derived AOD has an uncertainty of 0.01-0.021 due mainly to calibration (Eck et al., 1999). This AOD from the direct sun measurements is available for multiple wavelengths, and the spectral behavior of the AOD is used to compute the fine mode fraction (FMF) of the AOD. The algorithm of converting the spectral AOD to FMF is the Spectral Deconvolution Algorithm (SDA) developed by O'Neill et al. (2001a, 2003), which assumes a bimodal size distribution (i.e. coarse mode and fine mode). In applying the SDA to the AERONET direct-sun derived spectral AOD, the only assumptions made are (1) $\mathrm{AE}=-0.15$ and (2) $d(A E) / d \ln (\lambda)=0$ for the coarse mode (email correspondence with T. Eck). There is no assumption made at all about the fine mode. In other words, the AERONET SDA does not need to deal with size, refractive index or mixing status about fine mode particles. The AERONET SDA offers FMF at $500 \mathrm{~nm}$.

In this study, we use the FMF and AOD from direct sun measurements. The accuracy of this FMF depends primarily on the accuracy of the spectral AOD obtained from the direct sun measurements. Surface reflectance has a minor influence since AERONET measurements are made looking up at the sun, and so the FMF is almost as accurate over land as over ocean. Conversely, satellite derived FMF is much less 
accurate over land than over ocean, because satellite retrieval algorithms have to separate aerosol signal from strong land surface signal (in other words, surface reflectance heavily influences the derived AOD accuracy) and the spectral variation of land surface albedo has a lot of uncertainties.

In addition to the direct sun measurement, AERONET instruments make measurements of directional sky radiances in the almucantar geometry. Coupled with the direct measurement, these measurements are used to retrieve various optical properties (Eck et al., 2010). From the almucantar retrievals, multi-wavelength FMF and SSA are available. We do not use this FMF product here because the data from the almucantar retrievals are much less abundant than those from the direct sun measurement. Eck et al. (2010) showed that the FMF from the almucantar retrieval is very similar to that from the direct sun measurement.

We downloaded the monthly Level 2.0 (cloud-screened and quality-assured data) from AERONET Version 2 product, and the product includes the data from China. AE is obtained using the AOD at three wavelengths of 440, 675 and $870 \mathrm{~nm}$. We calculate AOD at $550 \mathrm{~nm}$, as follows. The $550 \mathrm{~nm}$ AOD is computed using logarithmic interpolation between AOD values at $500 \mathrm{~nm}$ and $675 \mathrm{~nm}$. If AOD value is not available at $675 \mathrm{~nm}$, values at $440 \mathrm{~nm}$ and $500 \mathrm{~nm}$ are extrapolated instead. If AOD value is not available at $500 \mathrm{~nm}$, values at $440 \mathrm{~nm}$ and $675 \mathrm{~nm}$ are interpolated. If AOD value is absent at two of these three wavelengths at least, then AOD is not obtained at $550 \mathrm{~nm} .500 \mathrm{~nm}$ AOD is obtained in a similar fashion. We generate the T42 version by calculating the arithmetic mean over each gridbox.

\subsection{GOCART}

The Georgia Tech/Goddard Global Ozone Chemistry Aerosol Radiation and Transport (GOCART) model simulates $550 \mathrm{~nm}$ AOD for major types of aerosols such as black carbon, organic carbon, sulfate, dust and sea salt (Chin et al., 2002). We use the GOCART simulation to fill up the gaps in the combined MODIS and MISR data. Such gaps are almost confined to the polar regions (as evident from Fig. 2a and $b$ ), and so the effect of using GOCART simulation on global AOD (or fAOD) is minimal. As far as the trend in regional mean AOD (and fAOD), the effect of GOCART simulation is close to zero, since we do not analyze the polar region in this study.

The GOCART model produces a global gridded AOD for each aerosol species at the $2.5^{\circ}$ latitude by $2.0^{\circ}$ longitude resolution, and the results are archived on a monthly scale from January 2000 to July 2002. A longer version from 2000 to 2007 is available at the Giovanni website (http://gdata1.sci.gsfc.nasa.gov/daac-bin/G3/ gui.cgi?instance_id=neespi), which we use here. From 2008 to 2010, we use the 2006-2007 average. The longer version does not include sea salt AOD, and we use the sea salt AOD seasonal climatology from the shorter version for each year. All these products are interpolated onto the T42 resolution.

The GOCART AOD is only available for $550 \mathrm{~nm}$, and so we calculate $\mathrm{AE}$ using the AOD for each type of aerosols, as below:

GOCART_AE $=$

$1.66 \times$ carbonaceous aerosol $+1.7 \times$ sulfate $+0.2 \times$ sea salt $+0.2 \times$ dust

Total AOD $(=$ black carbon + sulfate + organic carbon + sea salt + dust $)$

In Eq. (1), "black carbon" refers to the GOCART-simulated black carbon AOD. In the equation, the values such as 1.66, 1.7, etc. represent typical $\mathrm{AE}$ values for each aerosol species and are obtained as follows. The dust AE of 0.2 and the carbonaceous aerosol AE of 1.66 are from Chung et al. (2012). Sulfate AE is from Eq. (3) of Chung et al. (2005). Sea salt AE is assumed to be the same as dust AE. The intent of Eq. (1) is to roughly approximate the real $\mathrm{AE}$ over the gaps of the combined MODIS and MISR data.

\section{AOD and AE integration}

In this study, we integrate various aerosol datasets to produce the best estimates of AOD and fAOD. We also attempt to attain the best estimate of $\mathrm{AE}$ since $\mathrm{AE}$ will be used to derive our fAOD estimates. In this section, we describe the integration procedures for $\mathrm{AOD}$ and $\mathrm{AE}$.

\subsection{Aerosol optical depth (AOD)}

First, we compare monthly-mean AERONET AODs with MODIS and MISR AODs in Fig. 1. Such comparison made using instantaneous values (Chu et al., 2002; Remer et al., 2002, 2005; Kahn et al., 2005, 2010; Levy et al., 2007) revealed important differences between AERONET and MODIS/MISR data. The identified differences included systematic biases by MODIS/MISR. Satellite retrieval algorithms have been continually updated to reduce biases (e.g. Levy et al., 2007), which have been shown to be region or category dependent (e.g. Kahn et al., 2010). For example, Kahn et al. (2010) explained that MISR tends to overestimate AOD when AOD is low but tends to underestimate when AOD is high.

Monthly (mean) AOD can have additional differences from instantaneous values due to different sampling. For instance, AERONET, MODIS and MISR all attempt to derive data from non-cloud spots, and filter out data if deemed contaminated by cloud. This should result in differences in sampling clear and cloudy skies, given that AERONET, MODIS and MISR look for non-cloud spots to different extents and employ different cloud contamination removal algorithms. A CALIPSO (Cloud-Aerosol Lidar and Infrared Pathfinder Satellite Observations) study by Chand et al. (2009) showed that cloudy skies tend to have more aerosols (excluding aerosols inside cloud) than clear skies over the southern Atlantic Ocean, meaning that different sampling of clear 

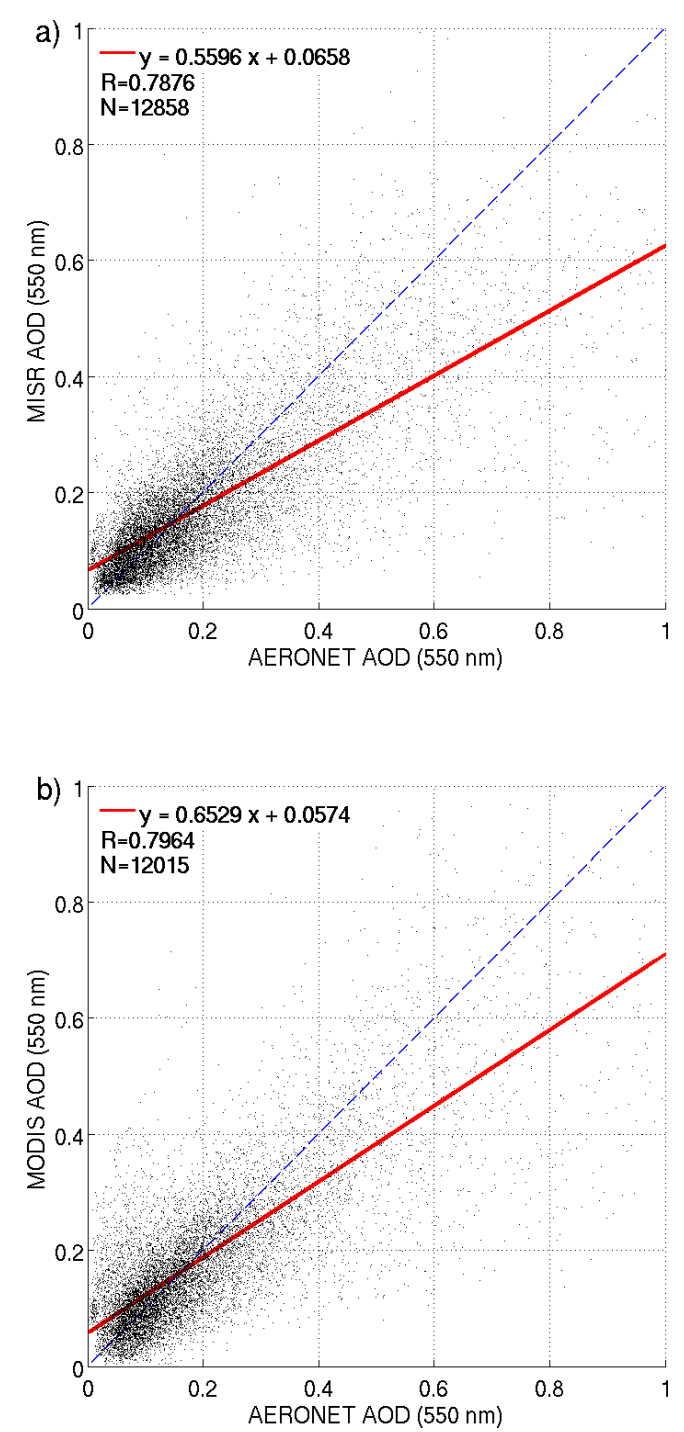

Fig. 1. (a) Comparison of monthly AERONET aerosol optical depths (AODs) and monthly MISR AODs collocated in time and space. (b) Comparison with MODIS AODs. The T42 data in the 2001-2010 period is used here. The solid red line in each panel represents the linear regression, and the dashed blue line shows a slope of 1.0. $R$ denotes the correlation coefficient, and $N$ the number of the collocated data.

and cloudy skies should contribute to further differences in monthly AOD while instantaneous AOD is irrelevant to these sampling differences. The direct sun measurement by AERONET instruments is made every $15 \mathrm{~min}$ and the AOD is retrieved as long as there is a gap in cloud between the sun and the instrument. In comparison, satellite retrieval algorithms look for clear sky pixels. The frequent AOD output in cloudy skies by AERONET, in our view, should make monthly AERONET data superior to monthly satellite AOD, not counting the problems in instantaneous AOD.
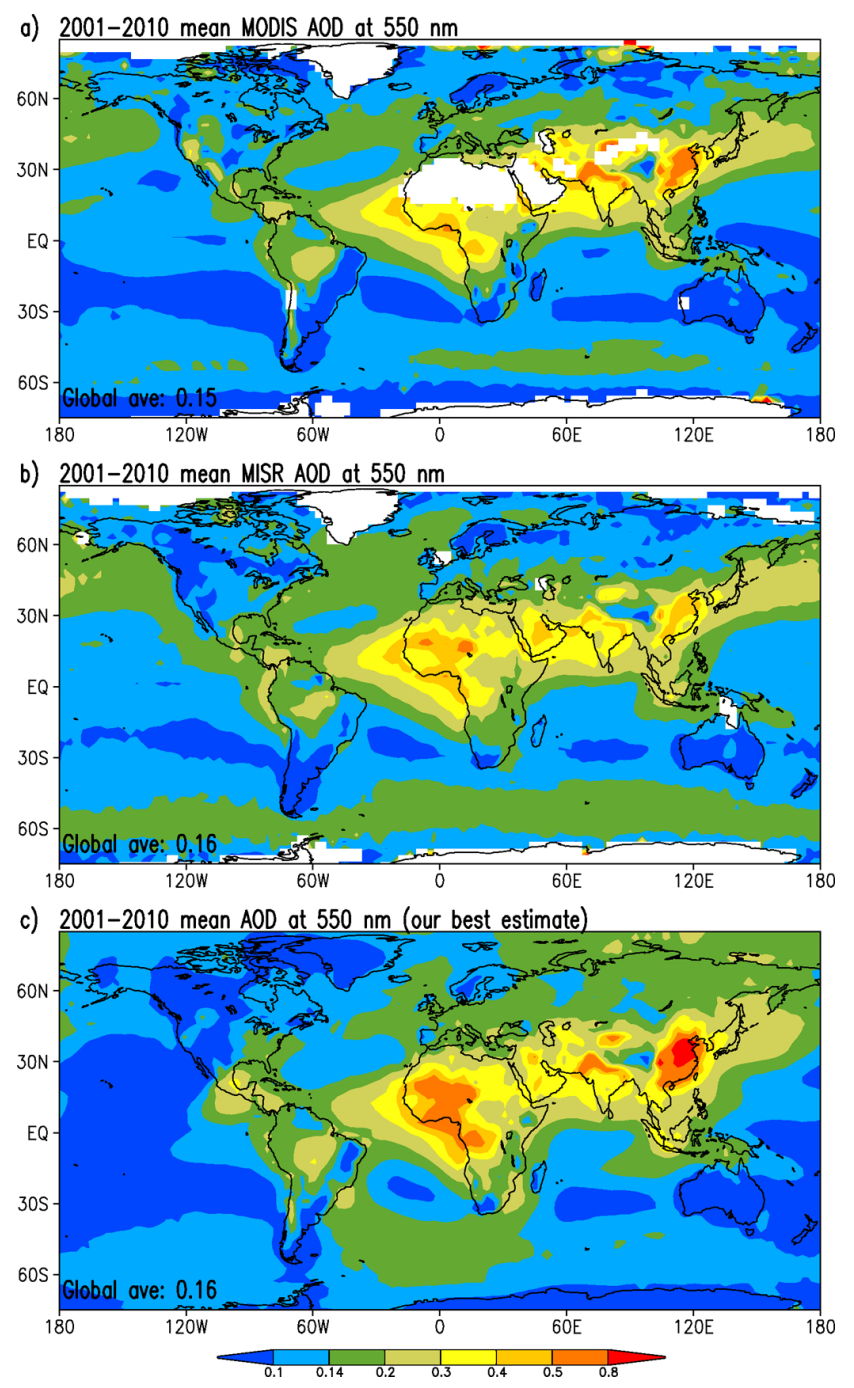

Fig. 2. Decadal mean AOD on the T42 resolution. Our best estimates, as shown in (c), integrate AERONET, MISR, MODIS, and GOCART data.

Very little on validating of monthly satellite-derived AOD exists. Chung et al. (2005; hereafter referred to as Chung2005 for brevity) found larger differences in monthly mean AOD between MODIS and AERONET than shown by instantaneous AOD investigation studies. In Chung2005, an older version of MODIS data was examined. In the present study, we use the latest version of MODIS AOD, and also include MISR data.

Here, we choose to validate monthly AODs at $550 \mathrm{~nm}$ with AERONET data as done in Chung2005. Given that each AERONET AOD represents a point in space and each satellite-derived AOD represents an area, the validation is performed with the T42 data. On the T42 resolution, AERONET, MODIS and MISR AODs all represent areas. We also validate the AOD data by interpolating MODIS and MISR AODs (before the T42 resolution conversion) onto 
AERONET site locations, and obtain nearly identical results. Figure 1 displays the comparison of AERONET, MODIS and MISR AOD. As shown in Fig. 1, MODIS AOD (or MISR AOD) is not strongly correlated with AERONET AOD. The correlation of about 0.8 is slightly lower than about 0.9 (Levy et al., 2010; Kahn et al., 2010) identified for instantaneous AOD. MODIS data are in slightly better agreement with AERONET AOD than MISR data are (Fig. 1). In contrast to correlation, the slopes in Fig. 1 correspond to the bias relative to AERONET AOD. The regression slopes are found to be 0.56 for MISR (Fig. 1a) and 0.80 for MODIS (Fig. 1b), again in support of the superiority of MODIS AOD over MISR AOD. Previous instantaneous AOD studies reported that the regression slopes of MODIS (or MISR) on AERONET are closer to 1.0 (Levy et al., 2010; Kahn et al., 2010). By comparing our results with instantaneous AOD study results, we conclude that monthly AODs by MODIS/MISR tend to have greater errors than instantaneous AODs.

We also compare the global and decadal (2001-2010) mean of AERONET, MODIS, and MISR AOD with the global and 3 yr (2001-2003) means in Chung2005. The mean AOD values are 0.19 for AERONET, 0.18 for MODIS, and 0.17 for MISR here, while Chung2005 found the mean AERONET AOD to be 0.18 and the mean MODIS AOD to be 0.26 . The most salient difference between the results here and those of Chung2005 is that the difference between AERONET and MODIS AOD is sharply reduced here, although it is acknolwdged that the global AERONET average is based on very sparse global sampling and therefore cannot be considered to be robust for a global average. Another noticeable difference is that MODIS and MISR now underestimate AODs compared to AERONET in contrast with the overestimated AOD by MODIS in Chung2005. The differences between Chung2005's MODIS AOD and the MODIS AOD here are more than the period and the retrieval algorithm. In this study, we use median values in the conversion of MODIS and MISR data from the original resolution into the T42 resolution, and this median method significantly reduces the number of extremely large values while this advanced scheme was not adopted by Chung 2005 .

In view of the aforementioned errors of monthly MODIS/MISR AOD, it would be ideal to use AERONET AOD alone. Because AERONET collects data from sparsely distributed measurement sites over the globe, the AERONET AOD gridded at the T42 resolution is dominated by gaps. To compensate for the data gaps, we combine the MODIS/MISR AOD with the AERONET AOD as in Chung2005. Chung2005 developed a methodology of retaining the spatial patterns of MODIS AOD and adjusting them with the AERONET AOD values. We apply a data combination method similar to that of Chung2005.

We generate the combined AERONET + MODIS + MISR 550-nm AOD as follows. All the datasets are on the T42 resolution before the combination. The data combination is conducted for each month from 2001 to 2010 . We use
GOCART simulations to fill the gaps in combined MISR and MODIS AOD. The MISR, MODIS, and AERONET AODs are combined so that the order of influence is AERONET $>$ MODIS $>$ MISR $>$ GOCART. MODIS seems to be more accurate than MISR in view of Fig. 1, and this is the basis for designing greater influence of MODIS than of MISR AOD. The data combination takes place in three steps: (i) The MISR AOD bias of 0.0286, compared to the AERONET AOD, is added to the MISR AOD at each grid. This bias is the global and decadal average of the difference between collocated AERONET and MISR AODs. We then fill the gaps of these MISR AODs with GOCART AODs using the interative difference-successive correction method developed by Cressman (1959). (ii) The MODIS AOD bias of 0.0110 is added to the MODIS AOD at each grid. Then, the gaps in the MODIS AODs are filled with the MISR + GOCART AOD again using Cressman's (1959) approach. (iii) The spatial pattern in the MODIS + MISR + GOCART AOD is coupled with the sparsely distributed AERONET AOD values, using Chung2005's technique, as below.

$N_{\mathrm{AOD} j}=\mathrm{MMG}_{\mathrm{AOD} j} \times \frac{\sum_{i} \frac{\operatorname{AERONET}_{j, i}}{d_{j, i}{ }^{4}}}{\sum_{i} \frac{\mathrm{MMG}_{\mathrm{AOD} j, i}}{d_{j, i}{ }^{4}}}$

where $N_{\mathrm{AOD} j}$ is the adjusted new value of the $\mathrm{AOD}$ at grid $j$; AERONET $_{j, i}$ is an AERONET AOD at station location $i$ nearby grid $j ; d_{j, i}$ is the distance between $j$ and $i$; and $\mathrm{MMG}_{\mathrm{AOD} j, i}$ is the MODIS + MISR + GOCART AOD at the grid of AERONET $_{j, i}$. Final AOD (i.e. $N_{\text {AOD }}$ ) is further adjusted to reproduce AERONET AOD wherever AERONET AOD exists. The last step (i.e. iii step) maximizes the influence of AERONET data, and can also be understood as follows. The regional bias of MODIS + MISR + GOCART AOD with respect to the AERONET AOD is removed, where the regional area size dynamically changes as a function of the availability of AERONET data. Although we remove regional biases in the (iii) step, we still remove the global bias in the (i) and (ii) steps because the (iii) step does not completely eliminate the global bias. Even if we do not remove the global biases in the (i) and (ii) steps, we obtain nearly identical products.

Note that the (iii) step assumes that AERONET data are always more accurate than satellite-derived AOD on the T42 resolution. Often a single AERONET AOD represents a T42 grid, and so this assumption would not be absolutely correct. The effect of the (iii) step is getting regional AOD averages right instead of getting the combined data over each grid right. Over a region (i.e. over multiple T42 grids), there are many AERONET data that should collectively be more accurate than satellite-derived data. The regional bias adjustment in the (iii) step is done over a region large enough to contain sufficient AERONET data. In case there is no AERONET data over a region (e.g. southern Pacific Ocean), very little change is made. 

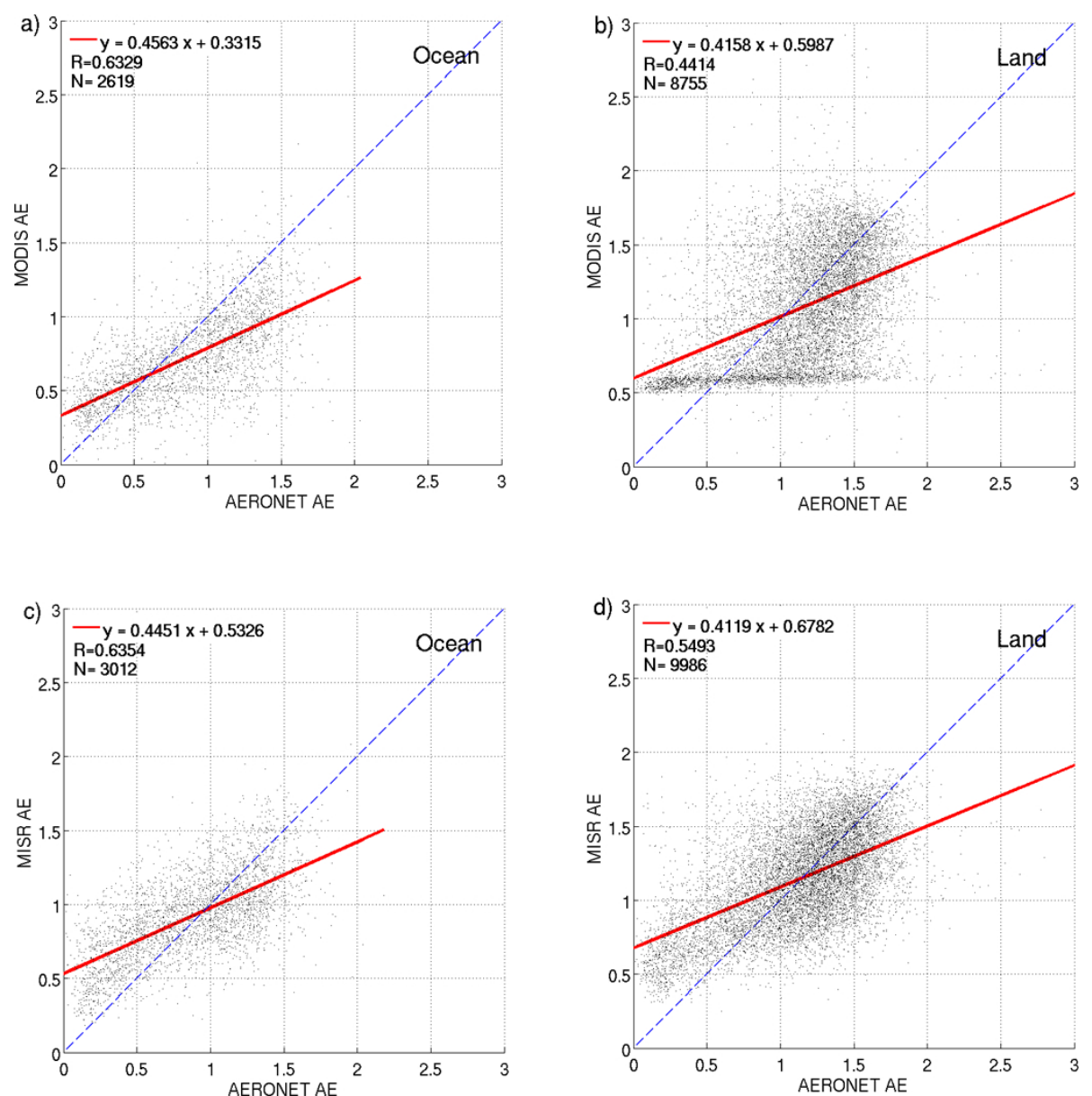

Fig. 3. Comparison of monthly AERONET AE and monthly MODIS (or MISR) AE. The data on the T42 resolution are used here.

Figure 2c shows the 2001-2010 mean of the combined AOD, which we also refer to as the integrated AOD or our best AOD estimate. AOD is large over eastern China, midAfrica and India, as expected. Satellite AODs (Fig. 2a and b) match our best AOD estimate in overall pattern and also over much of the globe in magnitude. However, the AOD maxima over eastern China and mid-Africa are severely underestimated in satellite AODs (Fig. 2a/b), by comparison to our integrated AOD (Fig. 2c). The differences between Fig. 2c and Fig. $2 \mathrm{a} / \mathrm{b}$ are mostly due to the regional adjustment of satellite AOD by AERONET AOD (as in step iii above). In other words, because the AERONET AOD tends to be systematically larger than satellite AOD over eastern China and mid-Africa but not elsewhere, our best AOD estimate shows larger AOD maxima over these regions. The global and decadal (2001-2010) mean of the best AOD estimate (as shown in Fig. 2c) is 0.16.

\section{2 Ångström exponent for AOD (AE)}

$\mathrm{AE}$ is known to give information about aerosol size (King et al., 1978; Nakajima et al., 1986; Kaufman, 1993; Eck et al.,
1999; O’Neill et al., 2001a, b, 2003; Schuster et al., 2006). $\mathrm{AE}$ is inversely proportional to particle size, and should be small over the ocean and deserts where aerosols are generally large. We combine monthly MODIS, MISR, AERONET and GOCART AEs for our best estimate of AE in the same way as we integrated various datasets for AOD in Sect. 3.1, except that we combine MODIS and MISR data as follows. We only use the MODIS AE over the ocean and use the MISR AE over the land. We choose to do this after investigating the MODIS and MISR AE in Figs. 3 and 4, as will be explained next.

The inadequacy of MODIS AE (and MODIS FMF) over land was pointed out by Levy et al. (2010). How about the MISR AE? Figure 3 shows that MISR AE is better correlated with AERONET AE than MODIS AE over the land. Also, the pattern of the MISR AE over land (Fig. 4a) is broadly consistent with our expectation, in that the deserts in Africa and Asia show low values while the biomass burning and industrial areas show large values. Over the ocean, conversely, the MODIS and MISR AEs exhibit similar degrees of correlation with the AERONET AE (Fig. 4a and c). In terms of spatial pattern, the MODIS AE is more consistent with our 


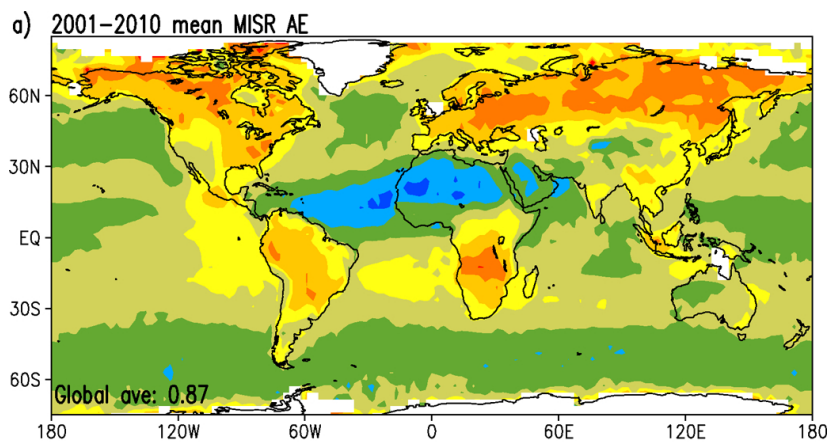

b) 2001-2010 mean MODIS AE
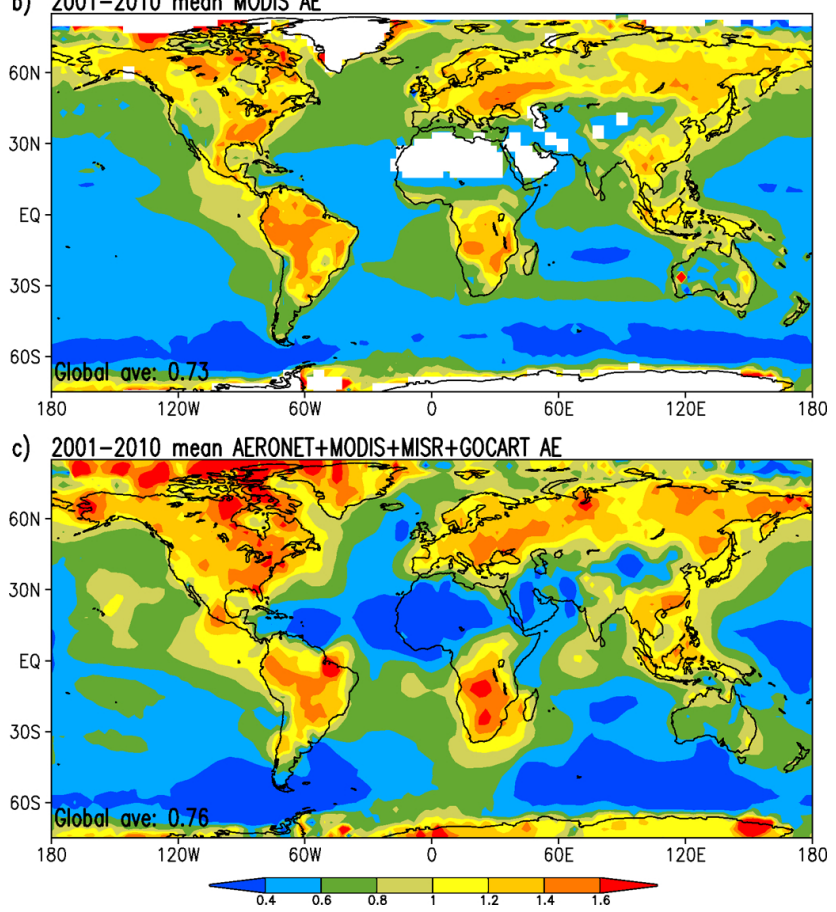

Fig. 4. Ångström exponent (AE) from (a) MISR, (b) MODIS, and (c) our best estimate. Shown are the 10-yr (2001-2010) AE averages, using the 10-yr mean AOD at each wavelength.

expectation. For instance, MISE AE shows that the AE over the northern tropical Atlantic is lower than over the Antarctic Circumpolar Current. Over the northern tropical Atlantic, aersols are mostly sea salt and transported dust from the Sahara while aerosols are mostly sea salt over the Antarctic Circumpolar Current. Transported dust particles are generally relatively small dust particles (Mahowald et al., 2005), and so we expect that particle sizes are at least as large over the Antarctic Circumpolar Current as over the northern tropical Atlantic. In this regard, the MODIS AE pattern is more reasonable than the MISR AE pattern over the ocean.

Our best AE estimate, which integrates AERONET, MODIS and MISR data, is displayed in Fig. 4c. The overall pattern is very consistent with the expected spatial distribution of average particle size. As shown in Fig. 4c, large $\mathrm{AE}$ values are dominant over the biomass burning areas and
Table 3. Definitions of fAOD, mAOD and cAOD. See Table 1 for the AOD acronyms. Only the MISR algorithm gives mAOD.

\begin{tabular}{lll}
\hline Measurement & Parameter & $\begin{array}{l}\text { Particle size definition } \\
\left(r_{\mathrm{p}}=\text { particle ratius) }\right.\end{array}$ \\
\hline \multirow{2}{*}{ AERONET } & fAOD & N/A (from SDA) \\
& cAOD & N/A (from SDA) \\
\hline \multirow{2}{*}{ MODIS } & fAOD & $r_{\mathrm{p}} \leqq 0.5 \mu \mathrm{m}$ \\
& cAOD & $0.5 \mu \mathrm{m}<r_{\mathrm{p}}$ \\
\hline \multirow{3}{*}{ MISR } & fAOD & $r_{\mathrm{p}}<0.35 \mu \mathrm{m}$ \\
& mAOD & $0.35 \mu \mathrm{m} \leqq r_{\mathrm{p}} \leqq 0.7 \mu \mathrm{m}$ \\
& $\mathrm{cAOD}$ & $0.7 \mu \mathrm{m}<r_{\mathrm{p}}$ \\
\hline
\end{tabular}

industrial regions. Compared to Fig. 4a, our best AE estimate shows larger values over the biomass burning region in Africa and smaller values over the central Asia, and this difference is a result of the sysmematic difference between the AERONET and MISR AE.

\section{Fine-mode aerosol optical depth (fAOD) integration}

For our best estimates of fAOD, we integrate AERONET, MODIS and MISR data and GOCART simulation as we did for AE. Applying the same integration method will not work, because AERONET, MODIS and MISR use different particle cut-off sizes to define fAOD (see Table 3). To overcome this problem, we design three integration methods. Before discussing the three methods in detail, we show how well the MODIS and MISR FMFs match the AERONET FMFs in Fig. 5. Figure $5 \mathrm{~b}$ demonstrates that MODIS FMF is totally inadequate for use over the land, corroborating the conclusion by Levy et al. (2010). MISR FMF seems to show some usefulness over land (Fig. 5d), as MISR AE does (Fig. 3d). Over the ocean, satellite-derived FMF is better correlated with the AERONET FMF than over the land. Satellite-derived AE is also better correlated with the AERONET AE over ocean (Fig. 3), confirming that satellite-derived AE and FMF are less reliable over the land. Between MISR and MODIS FMF over the ocean, MODIS data better correlate with AERONET data (Fig. 5a and c). In short, MODIS FMF and AE are better than MISR data over ocean, and MISR data are better over land.

In the following subsections, we discuss and evaluate the three methods.

\subsection{Method 1: using AE}

The overall strategy of the first method is to use AE to derive fAOD. As stated earlier, AE is related to FMF (Figs. 3, 5; O'Neill et al., 2001a, 2003). While MODIS, MISR and AERONET have different definitions of FMF, AE does not have the same issue. 

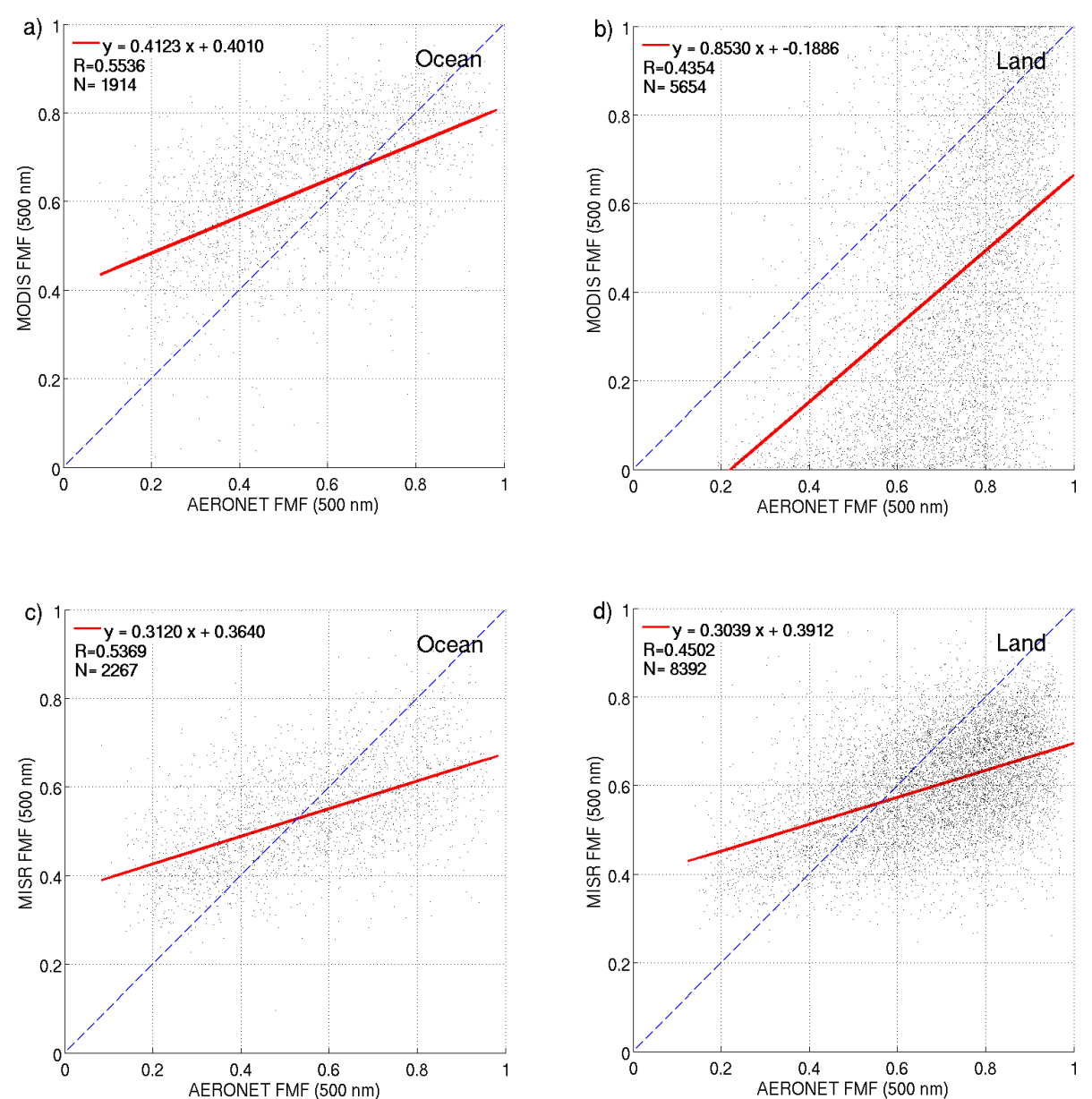

Fig. 5. Comparison of monthly AERONET FMF and monthly MODIS (or MISR) FMF. The data on the T42 resolution are used here. MISR FMF is defined as the ratio of fAOD to total AOD.

We first analyze the relationship between $\mathrm{AE}$ and $500 \mathrm{~nm}$ FMF using AERONET monthly data, as shown in Fig. 6. $\mathrm{AE}$ is correlated remarkably well with FMF, as was previously shown for individual AERONET sites using daily average data by Eck et al. (2010). Note the greater scatter for $\mathrm{AE}>1$ is largely due to the variability in radius of fine-mode aerosols resulting from fuel type differences, hygroscopicity and aging processes (Eck et al., 2003). We attempt to describe this relationship using a linear equation. This equation is intended to be an approximation, in order for our fAOD integration method to work. The equation is set to 1.0 if it exceeds 1.0 and is set to 0.0 if it is negative. The best fit linear equation is shown in Fig. 6.

The fAOD estimate is obtained, as follows. (i) This fitting equation is applied to compute global FMF using the integrated AE. (ii) The obtained FMF is multiplied by the integrated AOD to compute fAOD. (iii) This fAOD is adjusted by AERONET fAOD, using Eq. (2). (iv) If the adjusted fAOD $>$ AOD then fAOD is set to AOD, and if the fAOD $<0.0$ fAOD is set to 0.0 . These 4 steps constitute the first method.

\subsection{Method 2: also using AE}

This integration method is very similar to the first method. The steps are: (i) The fitting equation is applied to compute global FMF using the integrated AE. (ii) This FMF is adjusted by AERONET FMF, using Eq. (2). (iii) If the adjusted FMF $>1.0$ then it is set to 1.0 , and if the FMF $<0.0$ it is set to 0.0 . (iv) The FMF is multiplied by the integrated AOD to compute fAOD.

\subsection{Method 3: FMF integration}

The third method is based exclusively on FMF. The concept of the method is that differing definitions of fAOD create biases in FMF and we compute these biases for the correction.

This method consists of the following steps: (i) We use MISR FMF over land and use MODIS FMF over ocean. MODIS FMF at each grid is multiplied by 0.9054 and MISR FMF is multiplied by 1.1875 to bring them on a par with the AERONET FMF. MISR FMF is defined as the ratio of fAOD to total AOD. Gaps in MODIS and MISR FMFs are filled up 


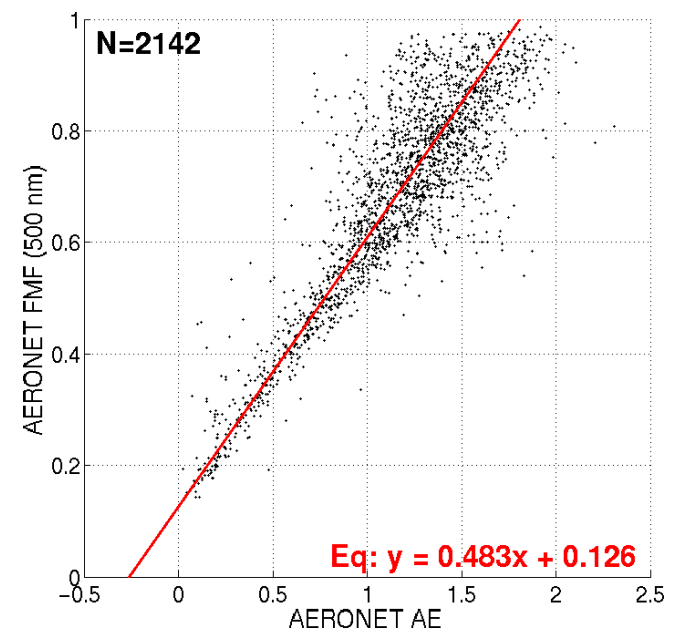

Fig. 6. Comparing monthly AERONET fine mode fraction (FMF) at $500 \mathrm{~nm}$ to monthly AERONET Ångström exponent (AE). The red line represents our best linear fit. The fitting equation $(\mathrm{Eq})$ and the number of data points $(N)$ are given in the plot.

by GOCART FMF using Cressman's (1959) method. GOCART fAOD is defined as the ratio of black carbon, organic aerosol and sulfate AODs combined to total AOD. (ii) The spatial pattern in the MISR + MODIS + GOCART FMF is coupled with the sparsely distributed AERONET FMFs, using Eq. (2). (iii) If this FMF $>1.0$ then it is set to 1.0, and if the FMF $<0.0$ it is set to 0.0 . (iv) The FMF is multiplied by the integrated AOD estimate to obtain fAOD.

\subsection{Which method works the best?}

We evaluate the three methods by conducting each method with fewer AERONET FMF data and then comparing the estimated FMF (or fAOD) with the unused AERONET FMF (fAOD) data. The unused AERONET data consist of unused FMF and AE on the same grids. The evaluation process is repeated with (randomly-chosen) different choices of the unused AERONET data. The random selection of the unused AERONET data is random in space and time. The discrepancies relative to the unused AERONET data are then averaged over the difference choices of the unused data.

We find that the best performing method is method 2 in various metrics such as FMF correlation, rms error for fAOD. Method 2, referred to as our best method hereafter, gives a FMF correlation of 0.55 over the globe $(0.47$ over land and 0.63 over ocean). This is certainly higher than the MODIS FMF gives over ocean (i.e. 0.55 as in Fig. 5a), and higher than the MISR FMF gives over land (i.e. 0.45). Note that even if our best method gives only as much correlation as MISR or MODIS FMF, our best method is still superior because the output is nearly at the AERONET data accuracy over the areas that contain enough AERONET data (since our best method integrated AERONET FMF data). The higher correlation means that even over the areas far from AERONET
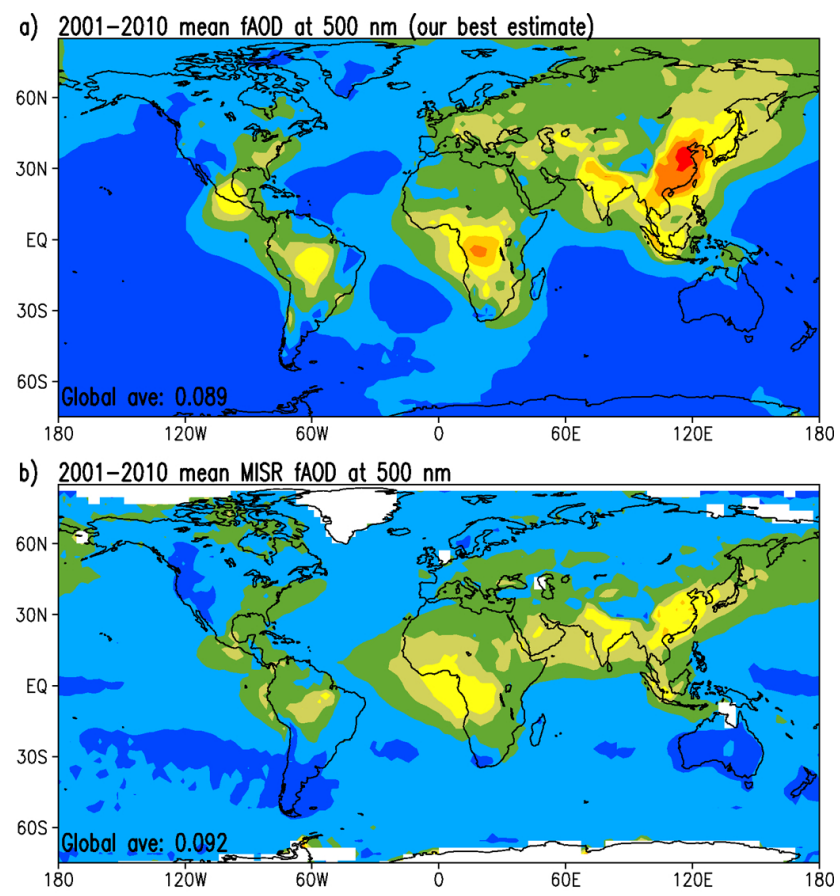

c) 2001-2010 mean MODIS fAOD at $550 \mathrm{~nm}$

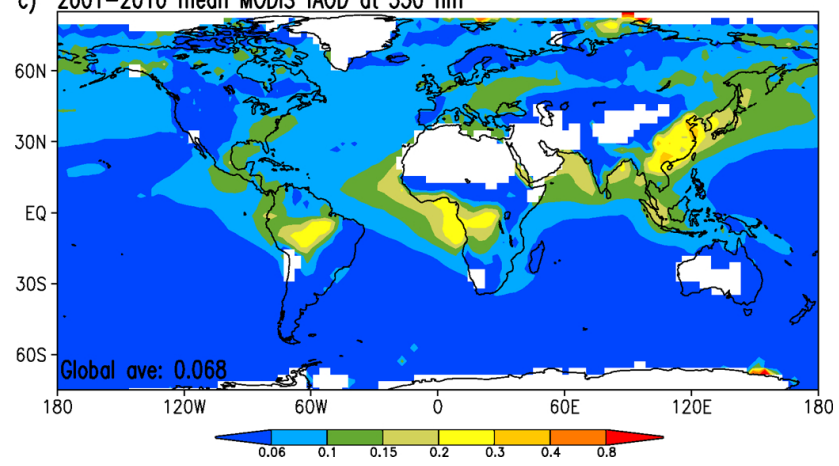

Fig. 7. Fine-mode AOD (fAOD) estimated by: (a) our best integration method; (b) MISR fAOD; and (c) MODIS fAOD.

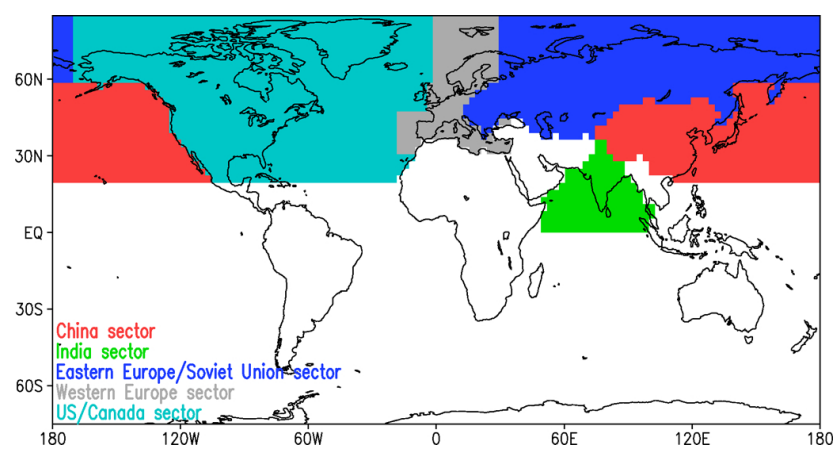

Fig. 8. Division of the world in this study. 
stations our best method works better than a simple use of MODIS or MISR FMF.

Figure 7a depicts our best fAOD estimate. The most noticeable feature in Fig. 7a is that fAOD is largest over eastern China. Compared to total AOD in Fig. 2c, fAOD is particularly large in China. Based on this, it is concluded that small (in size) aerosols are a major component of aerosols in eastern China. Our finding that aerosols in China are mostly made up of small particles cannot be reached using an AERONET data analysis alone, since there are so few AERONET stations in China. Compared to MODIS or MISR fAOD (Fig. 7b and c), the particularly strong fAOD over eastern China stands out as a unique aspect.

\section{Long-term trend in AOD and fAOD}

Long-term trends of atmospheric aerosol amounts have been receiving a significant amount of interest (Mishchenko et al., 2007; Herman et al., 2009; Zhang and Reid, 2010). Investigating long-term trends with satellite data is subject to a wide range of uncertainties such as calibration, noise, retrieval bias, and therefore such studies are challenging. In contrast, in generating our best estimates of AOD and fAOD we have nudged the combined MODIS + MISR data to AERONET data for each month, as explained in Sects. 3 and 4. Moreover, this nudging is stronger over land where there are relatively more AERONET data and MODIS (or MISR) AOD is less reliable. Thus, our integrated data do not overly suffer the aforementioned satellite data issues. On the other hand, the amount of AERONET data increased from 2001 to 2010 and this might create a spurious trend in our integrated data. In view of this, we look at the trend in our integrated data and then repeat the trend analysis with another version of the integrated data in which the AERONET data volume from 2002 is reduced to the 2001-2002 average level. In the data volume reduction, AERONET sites are randomly removed. For comparison, we also look at the time series of MODIS or MISR data alone. Our approach is an independent way to analyze decadal aerosol trends, and is an alternative to Zhang and Reid's (2010) study where they looked at the trend in each of MODIS, MISR and AERONET datasets instead of combining the datasets.

Figure 9 displays the time series of area-averaged annualmean AOD and fAOD from 2001 to 2010. The AOD and fAOD in Fig. 9 are from our best estimates. First focusing on the global average, AOD and fAOD were on the increase until 2005 and then decreased afterwards. This overall feature is also evident in the integrated data with the temporally-constant AERONET data volume. On the other hand, MODIS AOD alone (Fig. 10a) or MISR AOD alone (Fig. 10b) lacks this feature. Even a short-term strength in 2003 in global MODIS or MISR AOD is absent in our integrated data. All of these raise concerns about using current MODIS and MISR data in assessing global long-term trends.

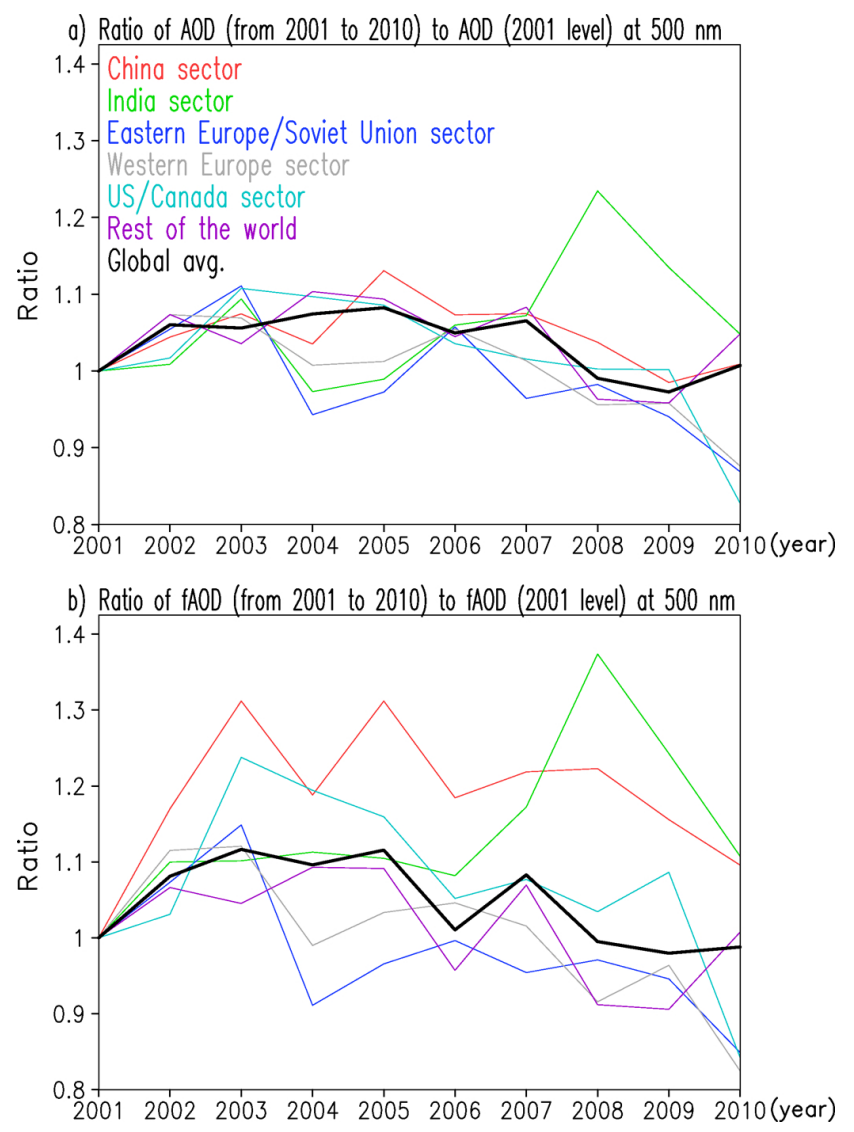

Fig. 9. Ratio of regionally averaged annual-mean AOD (or fAOD) to its 2001 level. Here, we use our best estimates of AOD (fAOD). See Fig. 8 for the division of the world.

Regarding the global average fAOD, there is a short-term reduction in 2006 and another reduction in 2008. The year2006 reduction comes significantly from South America (not shown), which is a source of a lot of biomass smoke. In the 2008 reduction, Southeast Asia as well as South America played an important role. Figure $9 \mathrm{~b}$ also shows that fAOD decreased in 2008 due partly to Western Europe. Because fossil fuel combustion is the dominant anthropogenic emission source in this region (Lamarque et al., 2010), this short-term fAOD reduction in Western Europe might have been associated with the economic recession in 2008. On the other hand, biomass burning, the source of which includes wild forest fire and indoor wood combustion, can be regarded as less dependent on overall economy.

Turning to regional averages, AOD and fAOD tended to decrease over the $10 \mathrm{yr}$ in US/Canada sector, Western Europe sector and Eastern Europe/Soviet Union sector (Fig. 9). For Western Europe and US/Canada combined, AOD and fAOD were down about $20 \%$ in the decade (Table $4 a$ ). This reduction is equally strong in the data with the temporarilyconstant AERONET data volume (Table 4a). On the contrary, MISR AOD shows no such features (Fig. 10b). MODIS AOD 
Table 4. Trend from 2001 to 2010 in units of AOD change and AOD percentage change over the 10 yr, (a) using our integrated data; and (b) only using AERONET data. The percentage inside of [] is the trend from the integrated data with the temporarily constant AERONET data volume. Linear trend is obtained from annual-mean values for each grid, and then average averages are made. "Eastern China" below refers to the $140-132^{\circ} \mathrm{E} / 24-52^{\circ} \mathrm{N}$ portion of China mainland, and "Western Europe" ("US/Canada") the land part of the Western Europe sector (US/Canada sector) in Fig. 8.

\begin{tabular}{lll}
\hline \multirow{2}{*}{ a) } & \multicolumn{2}{c}{ Area-averaged trend } \\
\cline { 2 - 3 } & AOD $(500 \mathrm{~nm})$ & fAOD $(500 \mathrm{~nm})$ \\
\hline India + eastern China & $-0.029(-6 \%):[-6 \%]$ & $0.0081(2 \%):[+3 \%]$ \\
\hline $\begin{array}{l}\text { Western Europe }+ \\
\text { US/Canada }\end{array}$ & $-0.028(-22 \%):[-22 \%]$ & $-0.016(-19 \%):[-19 \%]$ \\
\hline Global & $-0.0085(-5 \%):[-5 \%]$ & $-0.0073(-9 \%):[-7 \%]$ \\
\hline (b) & AOD $(500 \mathrm{~nm})$ & fAOD $(500 \mathrm{~nm})$ \\
\hline India + eastern China & $-0.0081(-1 \%)$ & $0.047(16 \%)$ \\
\hline $\begin{array}{l}\text { Western Europe }+ \\
\text { US/Canada }\end{array}$ & $-0.035(-27 \%)$ & $-0.032(-34 \%)$ \\
\hline Global & $0.026(12 \%)$ & $0.014(11 \%)$ \\
\hline
\end{tabular}

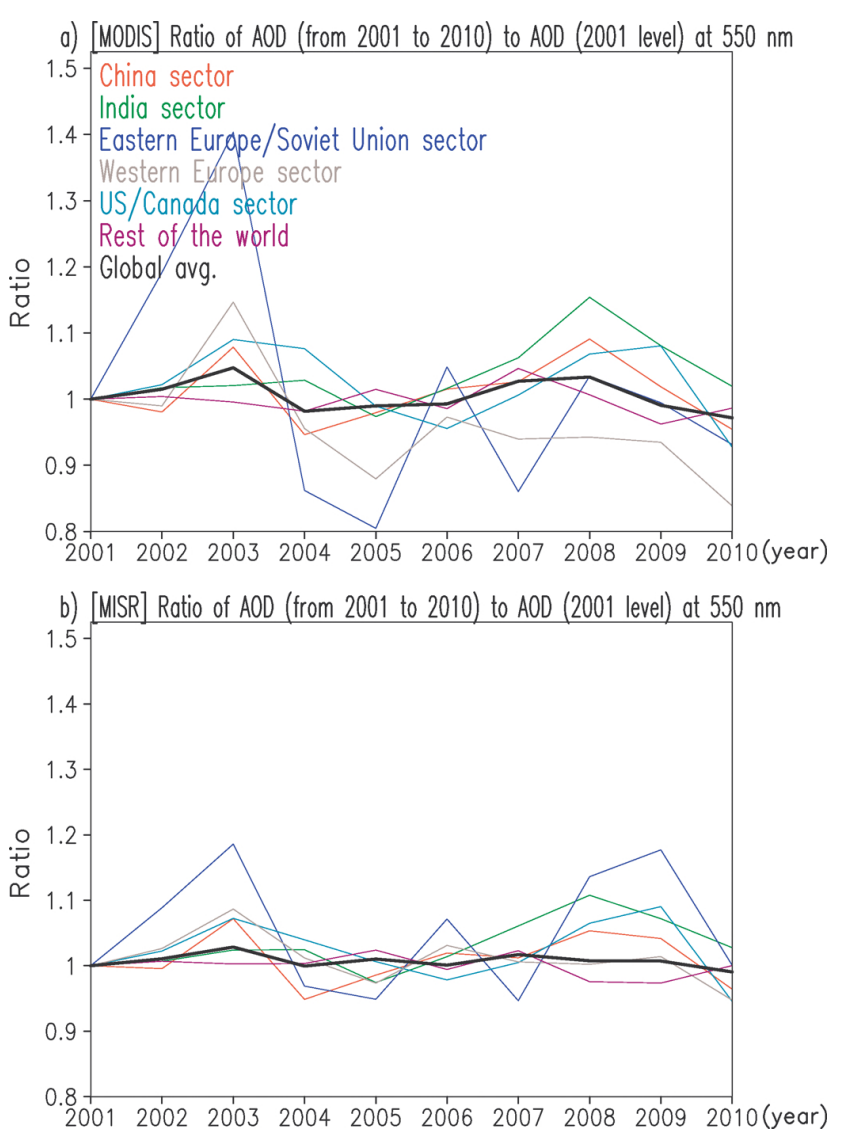

Fig. 10. Ratio of regionally averaged annual-mean AOD to its 2001 level. Here, we use MODIS and MISR data on the T42 resolution. shows a comparable reduction over Western Europe sector but a negligible reduction over US/Canada and Eastern Europe/Soviet Union sectors (Fig. 10a), again raising concerns about using satellite data in establishing long-term trends. In contrast to the West, fAOD had a mild increase in China and India sectors (Table 4a). In India and eastern China collectively, AOD decreased slightly while fAOD was up slightly. fAOD could only increase against a backdrop of decreasing AOD, if coarse-mode AOD decreases significantly. If coarsemode AOD, which mostly represents natural aerosols, did not change in this sector of the world, the level of PM would have gone up much more in this region.

Using AERONET data alone (Table 4b) reveals somewhat different trends than using the integrated data. For regional averages, the differences lie in the magnitude of the trend, and for the global average even the sign differs. AERONET sites represent a set of unevenly-located point observations and cannot properly represent a regional average, let alone the global average. The area-average fAOD estimates using the integrated data for trend analysis are one of the novelties of the present study.

Our finding that AOD and fAOD decreased in the West is broadly consistent with the identified brightening in various regions around the world. For instance, Long et al. (2009) reported a widespread brightening for $12 \mathrm{yr}$ (1995-2007) over the continental United State.

\section{Discussion}

Through this study, we have sought to provide more accurate estimates of global AOD, and fAOD by integrating 
MODIS, MISR and AERONET observations. Not only is our integrated AOD closer to AERONET data in accuracy than MODIS (or MISR) AOD alone over the globe, but our integrated fAOD is also closer to AERONET data globally. As stated earlier, satellite-based fAOD is not reliable over land while AERONET data abound over land. By combining AERONET data with MISR data, we have generated reliable fAOD data over land.

Our integrated data have a variety of uses. In one, our product can be used to validate aerosol simulations. Satellitebased AODs have been commonly used for such validation (e.g. Kinne et al., 2006) and in some cases (e.g. Myhre et al., 2009) AERONET AODs were used. Also, the ratio of fAOD to AOD can be used to roughly determine the anthropogenic fraction of total aerosol. As stated earlier, in the previous aerosol forcing estimation studies (e.g. Chung et al., 2005; Bellouin et al., 2005, 2008), the anthropogenic fraction was derived entirely or partially from aerosol simulations. Our global fAOD product offers a way to derive the anthropogenic fraction without using a model.

In this study, we have also demonstrated the usefulness of our product by analyzing the area averages of fAOD. Aerosol emission inventory studies (e.g. Lamarque et al., 2010; Smith et al., 2011) are subject to many uncertainties. For black carbon emission alone, there is a factor of 2 or more uncertainty in the estimates (Bond et al., 2013). Given these uncertainties, the time series of our fAOD area averages can be used to reduce the emission uncertainties.

Lastly, we have investigated the long-term trend of aerosols using our integrated data. We have analyzed the trend in global and regional mean aerosol amounts. Satellite data alone have many uncertainties in assessing long-term trends. We have attempted to overcome this problem by combining satellite and AERONET data. Since there is very little AERONET data coverage over some parts of the globe, the global average results need further validation studies.

Acknowledgements. The authors are thankful to Annica Ekman of Stockholm Univ. for stimulating discussions, and to Tom Eck of NASA for his expertise on AERONET data. This work was supported by the Korea Meteorological Administration Research and Development Program (CATER 2012-7101).

Edited by: J. H. Seinfeld

\section{References}

Bellouin, N., Boucher, O., Haywood, J., and Reddy, M. S.: Global estimate of aerosol direct radiative forcing from satellite measurements, Nature, 438, 1138-1141, doi:10.1038/nature04348, 2005.

Bellouin, N., Jones, A., Haywood, J., and Christopher, S. A.: Updated estimate of aerosol direct Radiative forcing from satellite observations and comparison against the centre climate model, J. Geophys. Res., 113, D10205, doi:10.1029/2007JD009385, 2008.
Bond, T. C., Doherty, S. J., Fahey, D. W., Forster, P. M., Berntsen, T., DeAngelo, B. J., Flanner, M. G., Ghan, S., Kärcher, B., Koch, D., Kinne, S., Kondo, Y., Quinn, P. K., Sarofim, M. C., Schultz, M. G., Schulz, M., Venkataraman, C., Zhang, H., Zhang, S., Bellouin, N., Guttikunda, S. K., Hopke, P. K., Jacobson, M. Z., Kaiser, J. W., Klimont, Z., Lohmann, U., Schwarz, J. P., Shindell, D., Storelvmo, T., Warren, S. G., and Zender, C. S: Bounding the role of black carbon in the climate system: A scientific assessment, J. Geophys. Res., doi:10.1002/jgrd.50171, 2013.

Chand, D., Wood, R., Anderson, T. L., Satheesh, S. K., and Charlson, R. J.: Satellite-derived direct radiative effect of aerosols dependent on cloud cover, Nat. Geosci., 2, 181-184, doi:10.1038/NGEO437, 2009.

Chin, M., Ginoux, P., Kinne, S., Torres, O., Holben, B. N., Duncan, B. N., Martin, R. V., Logan, J. A., Higurashi, A., and Nakajima, T.: Tropospheric aerosol optical thickness from the GOCART model and comparisons with satellite and sun photometer measurements, J. Atmos. Sci., 59, 461-483, 2002.

Christopher, S. A. and Wang, J.: Intercomparison between multiangle imaging spectroradiometer (MISR) and sunphotometer aerosol optical thickness in dust source regions over China: Implications for satellite aerosol retrievals and radiative forcing calculations, Tellus B, 56, 451-456, 2004.

Chu, D. A., Kaufman, Y. J., Ichoku, C., Remer, L. A., Tanré, D., and Holben, B. N.: Validation of MODIS aerosol optical depth retrieval over land, Geophys. Res. Lett., 29, 1617, doi:10.1029/2001GL013205, 2002.

Chung, C. E.: Aerosol direct radiative forcing: A review, in: Atmospheric aerosols - regional characteristics - chemistry and physics, edited by: Hayder Abdul-Razzak, ISBN: 978-953-510728-6, InTech, available at: http://www.intechopen.com/books/ atmospheric-aerosols-regional-characteristics-chemistry-and-physics/ aerosol-direct-radiative-forcing-a-review, 2012.

Chung, C. E., Ramanathan, V., Kim, D., and Podgorny, I. A.: Global anthropogenic aerosol direct forcing derived from satellite and ground-based observations, J. Geophys. Res., 110, D24207, doi:10.1029/2005JD006356, 2005.

Chung, C. E., Ramanathan, V., and Decremer, D.: Observationally constrained estimates of carbonaceous aerosol radiative forcing, P. Natl. Acad. Sci., 109, 11624-11629, 2012.

Cressman, G. P.: An operational objective analysis system, Mon. Weather Rev., 87, 367-374, 1959.

Dockery, D. W., Pope, C. A., Xu, X., Spengler, J. D., Ware, J. H., Fay, M. E., Ferris, B. G., and Speizer, F. E.: An Association between Air Pollution and Mortality in Six U.S. Cities, New Engl. J. Med., 329, 1753-1759, doi:10.1056/NEJM199312093292401, 1993.

Dubovik, O. and King, M. D.: A flexible inversion algorithm for retrieval of aerosol optical properties from Sun and sky radiance measurements, J. Geophys. Res., 105, 20673-20696, 2000.

Eck, T. F., Holben, B. N., Reid, J. S., Dubovik, O., Smirnov, A., O'Neill, N. T., Slutsker, I., and Kinne, S.: Wavelength dependence of the optical depth of biomass burning, urban, and desert dust aerosols, J. Geophys. Res., 104, 31333-31349, doi:10.1029/1999JD900923, 1999.

Eck, T. F., Holben, B. N., Reid, J. S., O’Neill, N. T., Schafer, J. S., Dubovik, O., Smirnov, A., Yamasoe, M. A., and Artaxo, P.: High aerosol optical depth biomass burning events: A comparison of optical properties for different source regions, Geophys. 
Res. Lett., 30, ASC 4-1-ASC 4-4, 2003.

Eck, T. F., Holben, B. N., Sinyuk, A., Pinker, R. T., Goloub, P., Chen, H., Chatenet, B., Li, Z., Singh, R. P., Tripathi, S. N., Reid, J. S., Giles, D. M., Dubovik, O., O’Neill, N. T., Smirnov, A., Wang, P., and Xia, X.: Climatological aspects of the optical properties of fine/coarse mode aerosol mixtures, J. Geophys. Res., 115, D19205, doi:10.1029/2010jd014002, 2010.

Gilgen, H., Wild, M., and Ohmura, A.: Means and trends of shortwave irradiance at the surface estimated from global energy balance archive data, J. Climate, 11, 2042-2061, 1998.

Herman, J. R., Labow, G., Hsu, N. C., and Larko, D.: Changes in cloud and aerosol cover (1980-2006) from reflectivitytime series using SeaWiFS, N7-TOMS, EP-TOMS, SBUV2, and OMI radiance data, J. Geophys. Res., 114, D01201, doi:10.1029/2007JD009508, 2009.

Holben, B. N., Eck, T. F., Slutsker, I., Tanré, D., Buis, J. P., Setzer, A., Vermote, E., Reagan, J. A., Kaufman, Y. J., Nakajima, T., Lavenu, F., Jankowiak, I., and Smirnov, A.: AERONET - A federated instrument network and data archive for aerosol characterization, Remote Sens. Environ., 66, 1-16, 1998.

Kahn, R. A., Gaitley, B. J., Martonchik, J. V., Diner, D. J., Crean, K. A., and Holben, B.: Multiangle Imaging Spectroradiometer (MISR) global aerosol optical depth validation based on 2 years of coincident Aerosol Robotic Network (AERONET) observations, J. Geophys. Res., 110, D10S04, doi:10.1029/2004JD004706, 2005.

Kahn, R. A., Gaitley, B. J., Garay, M. J., Diner, D. J., Eck, T. F., Smirnov, A., and Holben, B. N.: Multiangle Imaging SpectroRadiometer global aerosol product assessment by comparison with the Aerosol Robotic Network, J. Geophys. Res., 115, D23209, doi:10.1029/2010JD014601, 2010.

Kaufman, Y. J.: Aerosol Optical Thickness and Atmospheric Path Radiance, J. Geophys. Res., 98, 2677-2692, doi:10.1029/92JD02427, 1993.

Kaufman, Y. J., Tanré, D., Remer, L. A., Vermote, E. F., Chu, A., and Holben, B. N.: Operational remote sensing of tropospheric aerosol over land from EOS moderate resolution imaging spectroradiometer, J. Geophys. Res., 102, 17051-17067, doi:10.1029/96JD03988, 1997.

King, M. D., Byrne, D. M., Herman, B. M., and Reagan, J. A.: Aerosol Size Distributions Obtained by Inversions of Spectral Optical Depth Measurements, J. Atmos. Sci., 35, 2153-2167, 1978.

Kinne, S., Schulz, M., Textor, C., Guibert, S., Balkanski, Y., Bauer, S. E., Berntsen, T., Berglen, T. F., Boucher, O., Chin, M., Collins, W., Dentener, F., Diehl, T., Easter, R., Feichter, J., Fillmore, D., Ghan, S., Ginoux, P., Gong, S., Grini, A., Hendricks, J., Herzog, M., Horowitz, L., Isaksen, I., Iversen, T., Kirkevåg, A., Kloster, S., Koch, D., Kristjansson, J. E., Krol, M., Lauer, A., Lamarque, J. F., Lesins, G., Liu, X., Lohmann, U., Montanaro, V., Myhre, G., Penner, J., Pitari, G., Reddy, S., Seland, O., Stier, P., Takemura, T., and Tie, X.: An AeroCom initial assessment - optical properties in aerosol component modules of global models, Atmos. Chem. Phys., 6, 1815-1834, doi:10.5194/acp-6-1815-2006, 2006.

Lamarque, J.-F., Bond, T. C., Eyring, V., Granier, C., Heil, A., Klimont, Z., Lee, D., Liousse, C., Mieville, A., Owen, B., Schultz, M. G., Shindell, D., Smith, S. J., Stehfest, E., Van Aardenne, J., Cooper, O. R., Kainuma, M., Mahowald, N., Mc-
Connell, J. R., Naik, V., Riahi, K., and van Vuuren, D. P.: Historical (1850-2000) gridded anthropogenic and biomass burning emissions of reactive gases and aerosols: methodology and application, Atmos. Chem. Phys., 10, 7017-7039, doi:10.5194/acp10-7017-2010, 2010.

Levy, R. C., Remer, L. A., Kleidman, R. G., Mattoo, S., Ichoku, C., Kahn, R., and Eck, T. F.: Global evaluation of the Collection 5 MODIS dark-target aerosol products over land, Atmos. Chem. Phys., 10, 10399-10420, doi:10.5194/acp-10-10399-2010, 2010.

Levy, R. C., Remer, L. A., Mattoo, S., Vermote, E. F., and Kaufman, Y. J.: Second-generation operational algorithm: Retrieval of aerosol properties over land from inversion of Moderate Resolution Imaging Spectroradiometer spectral reflectance, J. Geophys. Res., 112, D13211, doi:10.1029/2006jd007811, 2007.

Liepert, B. G.: Observed reductions of surface solar radiation at sites in the United States and worldwide from 1961 to 1990, Geophys. Res. Lett., 29, 1421, doi:10.1029/2002GL014910, 2002.

Liu, Y., Sarnat, J. A., Coull, B. A., Koutrakis, P., and Jacob, D. J.: Validation of Multiangle Imaging Spectroradiometer (MISR) aerosol optical thickness measurements using Aerosol Robotic Network (AERONET) observations over the contiguous United States, J. Geophys. Res., 109, D06205, doi:10.1029/2003JD003981, 2004.

Long, C. N., Dutton, E. G., Augustine, J. A., Wiscombe, W., Wild, M., McFarlane, S. A., and Flynn, C. J.: Significant decadal brightening of downwelling shortwave in the continental United States, J. Geophys. Res., 114, D00D06, doi:10.1029/2008JD011263, 2009.

Mahowald, N. M., Baker, A. R., Bergametti, G., Brooks, N., Duce, R. A., Jickells, T. D., Kubilay, N., Prospero, J. M., and Tegen, I.: Atmospheric global dust cycle and iron inputs to the ocean, Global Biogeochem. Cy., 19, GB4025, doi:10.1029/2004gb002402, 2005.

Martonchik, J. V., Diner, D. J., Kahn, R., Gaitley, B., and Holben, B. N.: Comparison of MISR and AERONET aerosol optical depths over desert sites, Geophys. Res. Lett., 31, L16102, doi:10.1029/2004GL019807, 2004.

Mishchenko, M. I., Geogdzhayev, I. V., Rossow, W. B., Cairns, B., Carlson, B. E., Lacis, A. A., Liu, L., and Travis, L. D.: Long-term satellite record reveals likely recent aerosol trend, Science, 315, 1543-1543, doi:10.1126/science.1136709, 2007.

Myhre, G., Berglen, T. F., Johnsrud, M., Hoyle, C. R., Berntsen, T. K., Christopher, S. A., Fahey, D. W., Isaksen, I. S. A., Jones, T. A., Kahn, R. A., Loeb, N., Quinn, P., Remer, L., Schwarz, J. P., and Yttri, K. E.: Modelled radiative forcing of the direct aerosol effect with multi-observation evaluation, Atmos. Chem. Phys., 9, 1365-1392, doi:10.5194/acp-9-1365-2009, 2009.

Nakajima, T., Takamura, T., Yamano, M., Shiobara, M., Yamauchi, T., Goto, R., and Murai, K.: Consistency of Aerosol Size Distributions Inferred from Measurements of Solar Radiation and Aerosols, J. Meteorol. Soc. Jpn., 64, 765-776, 1986.

Norris, J. R. and Wild, M.: Trends in aerosol radiative effects over China and Japan inferred from observed cloud cover, solar "dimming", and sola "brightening”, J. Geophys. Res., 114, D00D15, doi:10.1029/2008JD011378, 2009.

O’Neill, N. T., Eck, T. F., Holben, B. N., Smirnov, A., Dubovik, O., and Royer, A.: Bimodal size distribution influences on the variation of Angstrom derivatives in spectral and optical depth space, J. Geophys. Res., 106, 9787-9806, 2001a. 
O’Neill, N. T., Dubovik, O., and Eck, T. F.: Modified Ångström exponent for the characterization of submicrometer aerosols, Appl. Optics, 40, 2368-2375, 2001b.

O’Neill, N. T., Eck, T. F., Smirnov, A., Holben, B. N., and Thulasiraman, S.: Spectral discrimination of coarse and fine mode optical depth, J. Geophys. Res., 108, 4559, doi:10.1029/2002JD002975, 2003.

Remer, L. A., Tanré, D., Kaufman, Y. J., Ichoku, C., Mattoo, S., Levy, R., Chu, D. A., Holben, B., Dubovik, O., Smirnov, A., Martins, J. V., Li, R. R., and Ahmad, Z.: Validation of MODIS aerosol retrieval over ocean, Geophys. Res. Lett., 29, 8008, doi:10.1029/2001GL013204, 2002.

Remer, L. A., Kaufman, Y. J., Tanré, D., Mattoo, S., Chu, D. A., Martins, J. V., Li, R. R., Ichoku, C., Levy, R. C., Kleidman, R. G., Eck, T. F., Vermote, E., and Holben, B. N.: The MODIS Aerosol Algorithm, Products, and Validation, J. Atmos. Sci., 62, 947-973, doi:10.1175/JAS3385.1, 2005.

Riihimaki, L. D., Vignola, F. E., and Long, C. N.: Analyzing the contribution of aerosols to an observed increase in direct normal irradiance in Oregon, J. Geophys. Res., 114, D00D02, doi:10.1029/2008JD010970, 2009.

Schuster, G. L., Dubovik, O., and Holben, B. N.: Ångström exponent and bimodal aerosol size distributions, J. Geophys. Res., 111, D07207, doi:10.1029/2005JD006328, 2006.

Schwartz, J. and Neas, L. M.: Fine particles are more strongly associated than coarse particles with acute respiratory health effects in schoolchildren, Epidemiology, 11, 6-10, 2000.

Smith, S. J., van Aardenne, J., Klimont, Z., Andres, R. J., Volke, A., and Delgado Arias, S.: Anthropogenic sulfur dioxide emissions: 1850-2005, Atmos. Chem. Phys., 11, 1101-1116, doi:10.5194/acp-11-1101-2011, 2011.

Stanhill, G. and Cohen, S.: Global dimming: A review of the evidence for a widespread and significant reduction in global radiation with discussion of its probable causes and possible agricultural consequences, Agr. Forest Meteorol., 107, 255-278, 2001.
Stanhill, G. and Moreshet, S.: Global radiation climate changes: The world network, Climatic Change, 21, 57-75, 1992.

Streets, D. G., Yan, F., Chin, M., Diehl, T., Mahowald, N., Schultz, M., Wild, M., Wu, Y., and Yu, C.: Anthropogenic and natural contributions to regional trends in aerosol optical depth, 1980-2006, J. Geophys. Res., 114, D00D18, doi:10.1029/2008JD011624, 2009.

Tanré, D., Kaufman, Y. J., Holben, B. N., Chatenet, B., Karnieli, A., Lavenu, F., Blarel, L., Dubovik, O., Remer, L. A., and Smirnov, A.: Climatology of dust aerosol size distribution and optical properties derived from remotely sensed data in the solar spectrum, J. Geophys. Res., 106, 18205-18217, doi:10.1029/2000JD900663, 2001.

van Donkelaar, A., Martin, R. V., Brauer, M., Kahn, R., Levy, R., Verduzco, C., and Villeneuve, P. J.: Global estimates of ambient fine particulate matter concentrations from satellitebased aerosol optical depth: Development and application, Environ. Health. Perspect., 118, 847-855, doi:10.1289/ehp.0901623, 2010.

Wild, M., Gilgen, H., Roesch, A., Ohmura, A., Long, C. N., Dutton, E. G., Forgan, B., Kallis, A., Russak, V., and Tsvetkov, A.: From Dimming to Brightening: Decadal Changes in Solar Radiation at Earth's Surface, Science, 308, 847-850, doi:10.1126/science.1103215, 2005.

Zhang, J. and Reid, J. S.: MODIS aerosol product analysis for data assimilation: Assessment of over-ocean level 2 aerosol optical thickness retrievals, J. Geophys. Res.-Atmos., 111, D22207, doi:10.1029/2005jd006898, 2006.

Zhang, J. and Reid, J. S.: A decadal regional and global trend analysis of the aerosol optical depth using a data-assimilation grade over-water MODIS and Level 2 MISR aerosol products, Atmos. Chem. Phys., 10, 10949-10963, doi:10.5194/acp-1010949-2010, 2010. 